\title{
EAHP launches COVID-19 resource centre for hospital pharmacists
}

\author{
Stephanie Kohl
}

The European Association of Hospital Pharmacists (EAHP) is closely monitoring developments linked to the novel coronavirus (COVID-19) across its member countries. To assist its member associations and individual hospital pharmacists in this critical time with the provision of the best possible care for patients, EAHP has decided to gather and make available information on COVID-19 relevant for the hospital pharmacy profession. The collected information has been included in EAHP's COVID-19 Resource Centre accessible via the Association's website (https://www. eahp.eu/hp-practice/hospital-pharmacy/ eahp-covid-19-resource-centre).

The COVID-19 Resource Centre seeks to ensure that hospital pharmacists are provided with up-to-date information and guidance on protection measures, surveillance and treatment options for patients infected with the disease. The initiator of the resource collection, EAHP President Petr Horák outlined: "Hospital pharmacists across Europe, are together with other medical personnel, at the forefront of fighting the coronavirus pandemic. The decision to launch EAHP's COVID-19 Resource Centre was taken to support the efforts of the hospital pharmacy profession and to facilitate the exchange of knowledge among different European countries. Sharing of best practices is vital to ensure the best care for our patients."

EAHP is encouraging hospital pharmacists to submit useful resources via the following email: covid19@eahp. eu. Materials in native languages can be shared. They should, however, be accompanied by a short English description and a translation of the name of the document into English to ease the orientation of the users of the resource centre. Information provided to EAHP will be made available in the Association's COVID-19 Resource Centre to ensure that as many individual hospital pharmacists as possible have access to best practices applied in other hospitals across Europe.

Correspondence to Ms Stephanie Kohl, Policy \& Advocacy, European Association of Hospital Pharmacists, Brussels, Belgium; Stephanie.Kohl@eahp. eu

182

\section{EAHP'S EUROPEAN LIST OF} EMERGENCY MEDICINES

Disasters such as storms, earthquakes and wildfires are happening more and more frequently. To better prepare hospital pharmacists - who are one of the fundamental cornerstones for effective and efficient performance of rescue operations before and during a catastrophe - EAHP has made available a European List of Emergency Medicines (ELEM).

The ELEM was developed after an evaluation of the most common causes of natural disasters in Europe, their consequences and the role of the hospital pharmacy before and during the catastrophe. The report, prepared by Dr D. Leonardi Vinci, Dr E. Di Martino, Dr R. Giammona, Dr M. E. Faggiano and EAHP Board members Dr P. Horák, Dr N. Miljković, Dr D. Makridaki and Dr P. Polidori, outlines how the ELEM was created including the criteria used and the considerations made which are specific for Europe, such as the reliable availability of different medicines.

Two support tools for clinicians, pharmacists and institutions have been made available, the disaster medicine assessment template and the disaster stock management template. The disaster medicine assessment template is based on the most relevant WHO emergency list and was adapted to the European scenario. It also includes a calculation sheet that quantifies the number of drugs needed and a self-assessment indicator that allows each hospital to rapidly evaluate its percentage of compliance with the proposed ELEM. The disaster stock management template enables the management of drug stocks during an emergency, automatically updates the quantity of stock available and keeps notes regarding all restock and withdrawal movements through a printable form. The ELEM can be accessed via the following link: https:// www. eahp.eu/practice-and-policy/ european-list-emergency-medicines.

\section{EUROPEAN HEALTH PROFESSIONAL ORGANISATIONS JOIN FORCES ON COVID-19}

At the end of March, EAHP together with other European health professionals and their students' organisations issued a
Joint Statement calling on the European Commission and the governments to support and protect healthcare professionals fighting COVID-19.

As Europe has become the global centre of the COVID-19 pandemic, healthcare professionals are working hard to contain the spread of the virus, putting themselves at risk to protect the communities. Despite the unprecedented efforts to stop the pandemic, healthcare professionals are at the front line without adequate personal protective equipment (PPE). The number of infections and deaths of the healthcare staff is increasing every day. Even in times of crisis, adequate working conditions must be ensured. Staff must have breaks and time off between shifts, to be able to carry on in what could be a long-term global crisis. The working time Directive should apply. Working in such conditions takes its toll on the psychological health of staff, so appropriate support services must also be put in place.

European healthcare professional organisations call on the European Commission to open a permanent line of communication with European health professionals to share experience and best practices across Europe and to ensure that the European Commission's support measures focus on operational priorities on the ground.

\section{EAHP'S ANNUAL REPORT FOR 2019 IS} OUT!

EAHP released its 2019 Annual Report which summarises the Association's achievements in the past year. The report shares information about EAHP's educational programme, projects, such as the Common Training Framework and the European Statements of Hospital Pharmacy, and advocacy work. Many activities centred around medicines shortages, a problem that is encountered by hospital pharmacists across all of EAHP's 35 member countries.

In addition to its Synergy Satellite Programme and its Synergy Masterclasses, EAHP introduced Synergy Certification Courses in 2019. This educational events allows hospital pharmacists and other healthcare professionals that don't have the opportunity to attend the Congress or other EAHP events to receive training on topics linked with the European Statements of Hospital Pharmacy. The Synergy Certification Courses are bilingual to ensure broad participation. Other milestones mentioned in the Annual report, include the fifth Anniversary of the European Statements of Hospital Pharmacy and the successful implementation of 
the Statement Implementation Learning Collaborative Centres (SILCC) programme.

\section{MOVE YOUR COUNTRY TOWARDS STATEMENT IMPLEMENTATION BY TAKING THE SAT}

Over 5 years ago, EAHP, together with other stakeholders, adopted the European Statements of Hospital Pharmacy which express commonly agreed objectives that every European health system should aim for in the delivery of hospital pharmacy services. One of the key drivers of the implementation of the European Statements is the online self-assessment tool (SAT) which has been made available to hospital pharmacists in 2018.

SAT allows hospital pharmacists to assess the level of implementation of the European Statements within their hospitals. It also provides the means for hospital pharmacists and other healthcare professionals to address areas needing improvement with the help of a tailormade action plan and a broad range of evidence-based resources. Progress can be tracked by individual hospital pharmacies as the assessment can be updated at any time. In addition, individual results can be compared with those of other hospitals in the same country.

Since EAHP is representing more than 23300 hospital pharmacists practicing all across Europe, SAT has been made available in 13 European languages, namely Czech, English, French, German, Greek, Hungarian, Italian, Polish, Portuguese, Romanian, Serbo-Croatian, Spanish and Turkish. EAHP encourages all hospital pharmacists, that have not yet tried out the tool, to assess their hospital pharmacies with the help of the SAT. A video tutorial has been made available to provide guidance. Hospital pharmacists can complete their SAT via the following link: http://sat. eahp.eu.

Competing interests None declared.

Provenance and peer review Commissioned: internally peer reviewed.

C European Association of Hospital Pharmacists 2020. No commercial re-use. See rights and permissions. Published by BMJ.

\section{A Check for updates}

To cite Kohl S. Eur J Hosp Pharm 2020;27:182-183.

Eur J Hosp Pharm 2020:27:182-183.

doi:10.1136/ejhpharm-2020-002306

ORCID iD

Stephanie Kohl http://orcid.org/0000-0003-0324-7976 